\title{
O DIREITO À NÃO AUTO-INCRIMINAÇÃO. A PROBLEMÁTICA DO TESTE DO BAFÔMETRO ${ }^{1}$
}

\author{
Mariana Thomé de Moraes ${ }^{2}$
}

\section{RESUMO}

Analisam-se as questões relevantes envolvendo o direito à não auto-incriminação sob a perspectiva do teste do bafômetro, buscando soluções de modo a adequar as exigências legais à ordem jurídico-constitucional em vigor, bem como propor soluções aptas a superar as controvérsias existentes conservando intactos direitos e garantias fundamentais.

Palavras-Chave: Bafômetro. Nemo tenetur se detegere. Obrigatoriedade. Lei $\mathrm{n}^{\mathrm{o}} 11.705 / 2008$.

\section{THE RIGHT AGAINST SELF-INCRIMINATION. THE PROBLEMATIC OF THE ETHILOMETER TEST}

\begin{abstract}
Are analised relevant questions involving the right against self-incrimination under the perspective of the ethylomether test, searching for solutions in a way to adequate the legal requirements to the operative legal-constitucional order, as well as offer solutions able to overcome the existing controversies, conserving fundamental rights and garanties intact.

Keywords: Ethylometer; Nemo tenetur se detegere; Obrigatoriness; Law $\mathrm{n}^{\circ}$ 11.705/2008.

\section{INTRODUÇÃO}

O advento da Lei $\mathrm{n}^{\circ} 11.705 / 2008$ fez emergir no seio social problemática antes restrita apenas aos manuais. Instauradora, em tese, de uma política de "tolerância zero" em relação

\footnotetext{
${ }^{1}$ Mariana Thomé de Moraes, servidora pública do Ministério Público do Estado do Rio de Janeiro, graduada pela Faculdade de Direito da UERJ. O presente trabalho consiste em uma adaptação da Monografia de conclusão de curso apresentada à Faculdade de Direito da UERJ pela autora. Contato: mary thome@ hotmail.com.

${ }^{2}$ A autora é servidora pública do Ministério Público do Estado do Rio de Janeiro, sendo o presente trabalho uma adaptação de sua Monografia de conclusão de curso apresentada à Faculdade de Direito da UERJ.
} 
àqueles que deliberadamente conduzem seus veículos embriagados, colocando em risco - ou mesmo ceifando - a vida de milhares, a denominada "Lei Seca" desencadeou profunda celeuma doutrinária e jurisprudencial no que tange à obrigatoriedade do condutor em se submeter ao principal meio de prova do estado de ebriez, qual seja, o etilômetro popularmente chamado de "bafômetro".

Sob esta perspectiva, através do presente trabalho buscar-se-á delinear a aplicabilidade do direito à não auto-incriminação - nemo tenetur se detegere - face à exigência legal, inserida no art. 306 do Código de Trânsito Brasileiro (CTB), de comprovação de concentração igual ou superior a seis decigramas de álcool por litro de sangue para fins de tipificação do delito de embriaguez ao volante, comprovação esta levada à cabo por meio de exame de sangue ou do teste do bafômetro.

\section{AS QUESTÕES FOMENTADAS PELA ALTERAÇÃO LEGISLATIVA}

A nova redação dada ao art. 306 do $\mathrm{CTB}^{3}$ ensejou profundas críticas doutrinárias ${ }^{4}$, tanto por parte dos que defendem a preeminência da prevenção de acidentes sobre o direito à não auto-incriminação, como dos que apregoam que a referida garantia constitucional deve prevalecer sem qualquer espécie de mitigação.

A efervescência de posicionamentos deriva do fato de que, de acordo com a literalidade da norma, somente o indivíduo comprovadamente com concentração superior a seis decigramas de álcool por litro de sangue poderia ser legítima e legalmente detido. Tal aferição, tão precisa, não poderia ser feita por outro meio que não o exame químicotoxicológico de sangue ou por meio do etilômetro, tendo em vista a supressão perpetrada pela nova redação da fórmula genérica "sob a influência de álcool".

Anteriormente à alteração legislativa em comento, a chamada "influência de álcool" poderia ser constatada por diversos meios, como exames periciais e mesmo a mera observação por parte das autoridades policiais nos casos mais latentes. Contudo, com a exigência de concentração específica de álcool no sangue, embora o art. 277 do CTB $^{5}$

\footnotetext{
${ }^{3}$ Art. 306 - Conduzir veículo automotor, na via pública, estando com concentração de álcool por litro de sangue igual ou superior a 6 (seis) decigramas, ou sob a influência de qualquer outra substância psicoativa que determine dependência: [...]

${ }^{4}$ Exempli gratia, Damásio Evangelista de Jesus.

5 Art. 277 - Todo condutor de veículo automotor, envolvido em acidente de trânsito ou que for alvo de fiscalização de trânsito, sob suspeita de dirigir sob a influência de álcool será submetido a testes de alcoolemia,
} 
mencione exames clínicos e periciais, na prática, a aplicação de tais métodos acabaria por violar o princípio da legalidade, eis que os mesmos não possuem a acuidade necessária para determinar com precisão a concentração de álcool por litro de sangue ${ }^{6}$.

Sob esta perspectiva, seria imprescindível, para fins de comprovação da conduta típica, a realização do denominado "teste do bafômetro" ou ainda de exame de sangue, este de caráter francamente invasivo.

Destarte, para se apurar a concentração precisa de álcool no sangue, como exige a norma em tela, seria preciso que o condutor adotasse conduta ativa no sentido de ceder amostragens de seu próprio corpo, no caso, sua expiração ou seu sangue.

No Brasil, a matéria está longe de ser pacífica. Há opiniões no sentido de defender a obrigatoriedade do teste do bafômetro, até mesmo por questões políticas: em razão dos crescentes índices de acidentes de trânsito cujos protagonistas são motorista embriagados, seria justificável sacrificar alguns valores em favor da sociedade. Em sentido oposto, há quem defenda que tal sacrifício não se justifica, e que o direito à não produzir prova contra si mesmo não deve submeter-se a mitigações de qualquer espécie.

Ambas os posicionamentos assentam-se em argumentos louváveis, que serão objeto de estudo aprofundado nas linhas que seguem.

\section{O REAL SENTIDO DO ARTIGO 306 DO CTB}

\subsection{A distinção entre as infrações administrativa e criminal previstas pelo CTB}

$\mathrm{O}$ art. 165 do $\mathrm{CTB}^{7}$ preceitua uma infração administrativa, determinando o pagamento de multa e a suspensão do direito de dirigir para aquele que dirigir sob influência de qualquer substância psicoativa causadora de dependência.

Analisando a norma em tela, tem-se como necessário o fato de "dirigir sob a influência de álcool ou de qualquer outra substância psicoativa que determine dependência",

exames clínicos, perícia ou outro exame que, por meios técnicos ou científicos, em aparelhos homologados pelo CONTRAN, permitam certificar seu estado. [...]

${ }^{6}$ PEREIRA, Danilo. Bom-bons criminosos, imposição de bafômetro e prisões: o Estado de Polícia. Disponível em http://www.ibccrim.org.br. Acesso em 09.06.2010.

${ }^{7}$ Art. 165. Dirigir sob a influência de álcool ou de qualquer outra substância psicoativa que determine dependência:

Infração - gravíssima;

Penalidade - multa (cinco vezes) e suspensão do direito de dirigir por 12 (doze) meses;

Medida Administrativa - retenção do veículo até a apresentação de condutor habilitado e recolhimento do documento de habilitação.

Parágrafo único. A embriaguez também poderá ser apurada na forma do art. 277. 
de modo que a ingestão das referidas substâncias não é suficiente para caracterizar a infração administrativa, sendo necessário que esteja acompanhada de comportamento decorrente do efeito psicotrópico das substâncias em questão.

Note-se que é necessária a presença concomitante da ingestão de substância psicoativa, da influência dessa substância sobre o indivíduo e da direção anormal, sendo estes requisitos cumulativos e sucessivos, de forma que a ausência de qualquer um impedirá a caracterização da infração.

Neste sentido, precisas são as lições de Damásio de Jesus:

Surpreendido o motorista dirigindo veículo, após ingerir bebida alcoólica, de forma normal, "independentemente do teor inebriante", não há infração administrativa, não se podendo falar em multa, apreensão do veículo e suspensão do direito de dirigir. Exige-se nexo de causalidade entre a condução anormal e a ingestão de álcool ${ }^{8}$.

O crime embriaguez ao volante em si, por sua vez, encontra-se tipificado pelo art. 306 do CTB, cuja mera leitura revela a existência de dois elementos do tipo: um objetivo e um subjetivo.

O elemento objetivo diz respeito à concentração igual ou superior a seis decigramas por litro de sangue, o que é aferido, cotidianamente, por meio do etilômetro. Realizando uma interpretação a contrario sensu, sendo a quantificação em questão inferior à prevista, inexistirá tipicidade e, consequentemente, delito.

Note-se que, a princípio e de acordo com a letra fria da lei, bastaria a presença de um dos termos desta última equação para que se alcançasse o resultado final, qual seja, a configuração do crime em estudo.

Ainda no que tange às diferenças entre a infração administrativa e o crime tipificado no art. 306 do CTB, cabe destacar uma segunda distinção, presente no art. $276^{9}$ do mesmo diploma legal, cujo parágrafo único confere ao CONTRAN - órgão do Poder Executivo

\footnotetext{
8 JESUS, Damásio Evangelista de. Embriaguez ao volante: notas à Lei $n^{o}$ 11.705/2008. Disponível em http://jus2.uol.com.br/doutrina/texto.asp?id=11510. Acesso em 23.01.2010.

${ }^{9}$ Art. 276. A concentração de seis decigramas de álcool por litro de sangue comprova que o condutor se acha impedido de dirigir veículo automotor.
}

Parágrafo único. O CONTRAN estipulará os índices equivalentes para os demais testes de alcoolemia. 
federal -, competência para definir os limites toleráveis de concentração de álcool no sangue em determinados casos.

Neste passo, foi editado o Decreto $n^{\circ} 6.488 / 2008$, o qual, em seu art. $1^{\circ}, \S 2^{\circ}$, fixou o limite em dois decigramas de álcool por litro de sangue para a generalidade dos casos, permitindo concluir que, estando a concentração abaixo deste limite, o fato será atípico tanto penal como administrativamente. Caso a concentração esteja entre dois e seis decigramas, haverá infração meramente administrativa. Contudo, se a concentração for igual ou superior a seis decigramas, resultando em direção anormal e exposição da segurança viária a risco, estará o agente incorrendo, concomitantemente, nas infrações administrativa e penal ${ }^{10}$.

Realizando-se uma interpretação sistemática do art. 276 do CTB, portanto, resta clara a importância da distinção, eis que, conforme se trate de uma infração administrativa ou criminal, os efeitos gerados serão mais ou menos gravosos, o que é de imensa relevância prática.

\subsection{Crime de perigo concreto ou abstrato?}

Na grande maioria das vezes, a sanção criminal somente ocorrerá no caso de efetiva lesão aos bens jurídicos penalmente tutelados - em geral, aqueles de maior relevância social. Todavia, há casos em que a lei penal autoriza a punição mediante a simples colocação de tais bens em situação de perigo, antecipando sua proteção, não sendo necessário que o dano realmente ocorra, bastando a simples probabilidade de sua ocorrência: são os chamados "crime de perigo" 11 .

Os crimes de perigo, por sua vez, subdividem-se em crimes de perigo abstrato e crimes de perigo concreto. Para que ocorra a configuração daqueles, não há necessidade de comprovação do perigo, trazendo a norma uma presunção absoluta de que, ocorrendo

\footnotetext{
${ }^{10}$ Cf. HC no 0041826-89.2009.8.19.0000, TJ/RJ, Oitava Câmara Criminal, Rel. Gilmar Augusto Teixeira, j. 18.11.2009.

11 ROMERO, Diogo. Reflexões sobre os crimes de perigo abstrato. Disponível em http://www.jus.com.br/Doutrina/texto.asp?id=5722. Acesso em 30.08.2010.
} 
determinada situação, o mesmo se fez presente ${ }^{12}$. Em relação a estes, contudo, é indispensável a comprovação da efetiva colocação em risco do bem jurídico protegido pela norma ${ }^{13}$.

No tocante à natureza do perigo exigido pelo art. 306 do CTB para que se perfaça o crime de embriaguez ao volante, a doutrina não é unânime, havendo quem entenda tratar-se de crime de perigo concreto, abstrato ou simplesmente de crime de perigo ${ }^{14}$.

Data venia, em que pese a diversidade de posições, o melhor entendimento ${ }^{15}$ é no sentido de que o crime previsto no mencionado dispositivo é de perigo concreto, não bastando a mera probabilidade de risco à segurança viária. Afinal, o fundamento jurídico deste tipo penal é a afetação dos bens jurídicos integridade física e vida, ou seja, não se proíbe a direção de veículo automotor da maneira prevista em si, mas sim porque tal conduta poderá lesionar os referidos bens jurídicos ${ }^{16}$.

Não se pode, contudo, falar simplesmente em perigo concreto, pois, no caso, face às peculiaridades da norma, trata-se de perigo concreto indeterminado, tendo em vista que, embora seja necessária a efetiva colocação de uma pessoa ou um grupo de pessoas em risco, tais indivíduos não são previamente identificados ${ }^{17}$.

Assim, considerar o crime de embriaguez ao volante como de perigo abstrato é grave equívoco, violando não apenas o caráter residual do Direito Penal, mas também o princípio da ofensividade, constitucionalmente assegurado e, desta forma, orientador do sistema jurídico como um todo.

\subsection{A interpretação sistemática do art. 306 do CTB}

Diante do exposto, temos que o delito previsto pelo art. 306 do CTB exige, para sua configuração, a coexistência de alguns requisitos, os quais, por sua vez, implicam em certas

\footnotetext{
${ }^{12}$ É preciso destacar que, a doutrina considera os crimes de perigo abstrato inconstitucionais face ao disposto no art. 98, I da Constituição Federal, o qual consagra, ainda que implicitamente, o princípio da lesividade ou da ofensividade, corolário do princípio da legalidade, constante no art. $5^{\circ}$, XXXIX, da Lei Maior. Neste sentido, posicionam-se, a título de exemplificação, Paulo Queiroz e Luiz Flávio Gomes.

13 ROMERO, Diogo. Reflexões sobre os crimes de perigo abstrato. Disponível em http:// http://www1.jus.com.br/Doutrina/texto.asp?id=5722. Acesso em 30.08.2010.

${ }^{14}$ Pode-se citar, exempli gratia, Sandro Caldeira Marron da Rocha, João Guilherme Marcondes e Damásio de Jesus, respectivamente.

${ }^{15}$ Defendido, dentre outros, por João Guilherme Marcondes.

${ }^{16}$ MARCONDES, João Guilherme. A política do bêbado zero e o tipo de perigo abstrato: análise da nova redação do Art. 306 do CTB. Disponível em http://www.ibccrim.org.br. Acesso em 27.06.2010.

${ }^{17}$ Cf. HC no 0041826-89.2009.8.19.0000, TJ/RJ, Oitava Câmara Criminal, Rel. Gilmar Augusto Teixeira, j. 18.11.2009.
} 
premissas que se deve ser levadas em consideração no momento da interpretação da norma em comento.

Por óbvio, não pode haver mais requisitos para a configuração da infração administrativa do que para a criminal, sob pena de total inversão dos valores e da lógica jurídicos. Caso contrário, aquela acabaria por demandar mais elementos para se perfazer do que esta, eis que o art. 165 do CTB exige a "influência" de álcool e o art. 306 do mesmo diploma legal, à primeira vista, não o faz. É latente o absurdo da situação, tendo em vista a maior gravidade intrínseca às normas penais.

Desta forma, em suma, são requisitos para que se perfaça o tipo penal atualmente constante no art. 306 do CTB:

- Condução de veículo automotor em via pública;

- ingestão anterior ou concomitante de substância alcoólica ou de efeitos análogos; [...]

- condução anormal, de acordo com as regras de circulação viária: conduta imprudente, descuidada ou perigosa;

- nexo de causalidade entre a condução anormal e a ingestão de substância alcoólica ${ }^{18}$.

Neste diapasão, não basta, para a configuração do delito de embriaguez ao volante, a simples concentração de álcool no sangue acima do legalmente tolerado para fins de direção de veículo automotor, sendo preciso que o motorista tenha seu comportamento alterado em decorrência do consumo de bebida alcoólica. Em outras palavras, é imprescindível a existência de nexo de causalidade entre o referido consumo e a direção anormal ${ }^{19}$.

Outro ponto a se considerar é a natureza de crime de perigo concreto indeterminado do delito em análise, de modo que não é suficiente, para sua configuração, a mera presunção de

\footnotetext{
${ }^{18}$ JESUS, Damásio Evangelista de. Notas ao art. 306 do Código de Trânsito: Crime de embriaguez ao volante. Disponível em http://www.ibccrim.org.br. Acesso em 23.06.2010.

${ }^{19}$ É este o entendimento desposado, de modo geral, pelo Tribunal de Justiça do Estado do Rio de Janeiro, o qual vem progressivamente pacificando a posição de serem a concentração de álcool no sangue e a direção influenciada pelo álcool requisitos cumulativos para fins de caracterização do delito em tela. Neste sentido, vide HC no 0032901-70.2010.8.19.0000, TJ/RJ, Sétima Câmara Criminal, Rel. Alexandre H. Varella, j.03.08.2010; Apelação Criminal nº 0052960-76.2010.8.19.0001, TJ/RJ, Quarta Câmara Criminal, Rel. M. Sandra Kayat Direito, j.03.08.2010; $\mathrm{HC} \mathrm{n}^{\circ}$ 0033053-21.2010.8.19.0000, TJ/RJ, Des. Eunice Ferreira Caldas, Oitava Câmara Criminal, j.04.08.2010 e HC no 0030923-58.2010.8.19.0000, TJ/RJ, Des. Maria Helena Salcedo, Quinta Câmara Criminal, j. 29.07.2010. No mesmo sentido já se manifestou o Supremo Tribunal Federal, resolvendo contrariamente à decisão monocrática anteriormente proferida pelo Superior Tribunal de Justiça, valendo consultar o HC no 100.472, STF, Rel. Eros Grau, j. 27.08.2009. Contrariamente, a Terceira Câmara Criminal do Tribunal de Justiça do Estado do Rio de Janeiro vem entendendo ser o delito de embriaguez ao volante de perigo abstrato, dispensada a comprovação de influência de álcool, cf. HC nº 0026672-94.2010.8.19.0000.
} 
perigo, sendo essencial que o motorista, uma vez embriagado, conduza o veículo de forma anormal, colocando efetivamente em risco a incolumidade de um grupo de pessoas, normalmente não determinado a priori.

Entender em sentido contrário implicaria na antecipação do momento consumativo do crime, simulando existir conduta que ainda não se concretizou e que pode, mesmo, sequer vir a ocorrer, tendo em vista ser plenamente possível que o condutor, ainda que em estado de ebriez, não atinja ou ameace o bem jurídico penalmente tutelado pela norma em apreço ${ }^{20}$.

Tal entendimento coaduna-se perfeitamente com o que deflui da distinção entre o ilícito penal e o administrativo, sendo necessário, além do nexo causal entre a embriaguez e a direção anormal, o oferecimento real de risco a outrem.

Neste passo, insta trazer à colação a interpretação proposta por Damásio de Jesus:

Dividido o tipo penal em duas partes, pois cremos que foi essa a intenção do legislador, temos que a primeira reza:

"Conduzir veículo automotor, na via pública, estando com concentração de álcool por litro de sangue igual ou superior a 6 (seis) decigramas."

A segunda parte dispõe:

("Conduzir veículo, na via pública,) estando [...] sob a influência de qualquer outra substância [...]" (grifo nosso).

Na primeira parte, referente a álcool, nenhuma referencia à influência etílica.

Na segunda, concernente a qualquer outra substância, expressa exigência de influência alcoólica ${ }^{21}$.

Sob esta perspectiva, uma interpretação meramente literal da norma seria completamente inadequada, conclusão esta obtida mediante um estudo integrado das normas da Lei sob exame, encaradas como um sistema harmônico e coeso e não como comandos isolados ${ }^{22}$.

${ }^{20}$ Cf. HC no 0041826-89.2009.8.19.0000, TJ/RJ, Oitava Câmara Criminal, Rel. Gilmar Augusto Teixeira, j. 18.11.2009.

${ }^{21}$ JESUS, Damásio Evangelista de. Embriaguez ao volante: notas à Lei $n^{\circ}$ 11.705/2008. Disponível em http://jus2.uol.com.br/doutrina/texto.asp?id=11510. Acesso em 23.01.2010.

${ }^{22}$ A interpretação sistemática soluciona ainda uma crítica freqüentemente destinada ao etilômetro: trata-se do argumento científico de que diferentes pessoas possuem diferentes níveis de tolerância ao álcool, de modo que haverá indivíduos que, inobstante estarem com a concentração de álcool no sangue acima do tolerado pela lei, estarão em total controle de suas faculdades mentais e, conseqüentemente, dirigindo normalmente. Considerando-se que para que o crime ocorra será preciso, além da ingestão de álcool acima do legalmente permitido para guiar um veículo, a chamada "direção anormal", esses indivíduos mais resistentes não serão 
Neste sentido, cabe atentar para o fato de o CTB reiterar a exigência da influência de álcool em diversos dispositivos ${ }^{23}$, deixando claro que circunstância integra o tipo penal do art. 306 do CTB, devendo ser considerada de forma conjunta com a ingestão de álcool.

Irretocáveis são as palavras de Damásio de Jesus ao se manifestar acerca do tema:

Por meio de interpretação sistemática, vê-se que o espírito da norma, considerada em face do todos, é o de considerar praticado o crime de embriaguez ao volante somente quando o condutor está sob a influência de substância alcoólica ou similar, que tem o significado de direção anormal.

Seria impróprio que o legislador, no tocante a álcool, considerasse a existência de crime de embriaguez ao volante só pela presença de determinada quantidade no sangue e, no caso de outra substância, exigisse a influência. Como esta possui o conceito de condução anormal, seria estranha a sua exigência na redação da infração administrativa e sua dispensa na definição do crime $^{24}$.

Diante do exposto, temos que o art. 306 do CTB pode gerar perplexidades à primeira vista e, até mesmo, conduzir a uma interpretação equivocada. Contudo, resta claro que, mediante uma interpretação atenta tanto ao universo do CTB como ao ordenamento jurídicoconstitucional em vigor, o real sentido da norma se revela, caindo por terra o véu de obscuridade que provoca tantas confusões ao se tratar da chamada "Lei Seca".

\section{O PRINCÍPIO dO NEMO TENETUR SE DETEGERE SOB A PERSPECTIVA DO TESTE DO BAFÔMETRO}

\subsection{Os meios de prova da embriaguez ao volante}

prejudicados, pois, desde estejam dirigindo de maneira normal, a concentração de álcool em seu sangue não poderá ser utilizada isoladamente como fundamento para imputar-lhes o crime de embriaguez ao volante.

${ }^{23} \mathrm{O}$ art. $4^{\circ}$-A, acrescido ao CTB pela Lei 11.705/2008 dispõe que "Na parte interna dos locais em que se vende bebida alcoólica, deverá ser afixado advertência escrita de forma legível e ostensiva de que é crime dirigir sob a influência de álcool, punível com detenção". No mesmo sentido preceitua o $1^{\circ}$ do art. 291 do CTB, ao referirse, no seu inciso I, à "influência de álcool ou qualquer outra substância psicoativa que determine dependência;" [...] (Grifos nossos).

24 JESUS, Damásio E. de. Embriaguez ao volante: notas à Lei $n^{o}$ 11.705/2008. Disponível em http://jus2.uol.com.br/doutrina/texto.asp?id=11510. Acesso em 23.01.2010. 
Ao exigir uma concentração específica de álcool por litro de sangue, a nova redação do art. 306 do CTB inovou em relação à anterior, que exigia tão somente a direção "sob influência de álcool ou substância de efeitos análogos”. Assim, em que pese a conhecida intenção do legislador de recrudescer a Lei, reduzindo os acidentes e mortes no trânsito, tal alteração acabou por dificultar - se não impossibilitar - a tipificação do delito em comento.

Trata-se de um lamentável erro legislativo que transformou aquela concentração em verdadeira elementar do tipo constante no art. 306 do CTB, embora alguns doutrinadores ${ }^{25}$, membros do Parquet e magistrados, ávidos por uma maior - e, admita-se, justificada punição defendam a dispensabilidade da realização do exame de sangue e do teste do bafômetro para que se perfaça o crime de embriaguez ao volante ${ }^{26}$.

Contudo, permissa venia, é inegável que, com o advento da Lei $\mathrm{n}^{\circ} 11.705 / 2008$, a concentração de álcool por litro de sangue passou a ser, ao lado da direção influenciada pelo álcool, elementar do tipo penal em estudo, de modo que se afigura imprescindível a presença concomitante de ambas, sob pena de atipicidade.

Tal concentração, contudo, não pode ser aferida a olho nu, seja por agentes de trânsito, seja por médicos, sendo imperativo o emprego de métodos aptos a verificar, com precisão, a quantidade de álcool no sangue, lavrando-se o competente Auto de Exame de Corpo de Delito. É sabido que, ao menos no atual estágio do desenvolvimento científico, os únicos meios disponíveis para tanto são o exame de sangue e o teste do bafômetro.

O exame clínico, realizado por médico-perito, revestia-se de enorme valia à época da vigência da antiga redação do dispositivo em tela. Todavia, com as atuais exigências trazidas pelo mesmo, tal exame tornou-se, em verdade, completamente inócuo, tendo em vista que, por melhor que seja a formação do médico e por mais vasta que seja sua experiência, um ser humano não pode, per se, determinar com precisão a concentração de álcool por litro de sangue, conforme exigido pela nova Lei.

\footnotetext{
${ }^{25}$ Ver, por todos, Rogério Schietti Machado Cruz.

${ }^{26}$ Sob esta perspectiva, certos julgadores - infelizmente, até mesmo do Superior Tribunal de Justiça - insistem em defender a prescindibilidade do teste do bafômetro para efeitos de tipificação do delito de embriaguez ao volante, inobstante a elementar referente à concentração específica de álcool no sangue inserida pela Lei $\mathrm{n}^{\circ}$ 11.705/2008. À guisa de exemplificação, cabe consultar a Apelação Criminal n 2009.007530-3, TJRS, Segunda Câmara Criminal, Rel. Irineu João da Silva, j. 22.06.2009, o HC n ${ }^{\circ}$ 132374/MS, STJ, Rel. Ministro Felix Fischer, Quinta Turma, DJe 16.11.2009 e HC n ${ }^{\circ} 151087$ / SP, STJ, Quinta Turma, Rel. Ministro Napoleão Nunes Maia Filho, DJe 26.04.2010.
} 
Destarte, embora um médico-perito possa contribuir substancialmente para comprovar a elementar da influência de álcool, sua participação isolada será inútil para que reste comprovada a quantidade de álcool no sangue do condutor.

Segundo a corrente que insiste na dispensabilidade do teste do bafômetro, o médicolegista poderia atestar com certeza que determinado indivíduo estaria com concentração de álcool no sangue acima do legalmente permitido com base em sinais externos de embriaguez. Todavia, tal entendimento deixa de considerar o conhecimento científico ${ }^{27}$ - e mesmo cotidiano - de que diferentes pessoas possuem tolerância diversa ao álcool, de modo que um indivíduo pode ter concentração de álcool por litro de sangue abaixo de seis decigramas e comportar-se como se tivesse ingerido maior quantidade de bebida alcoólica e vice-versa.

Conclui-se, destarte, que a prisão em flagrante baseada tão somente na percepção subjetiva do médico pode facilmente transmudar-se em ilegalidade, eis que é possível - e, quiçá, provável - que ocorra a privação do status libertatis do indivíduo sem sequer haver tipicidade, eis que ausente uma das elementares do tipo.

Por fim, cabe destacar que parte da doutrina ${ }^{28}$ afirma que, caso se negue a soprar o bafômetro ou a fornecer amostragens de seu sangue, havendo justa causa, o motorista poderá ser conduzido coercitivamente ao Instituto Médico-Legal para a realização do exame clínico. Com a devida vênia, quem atestará a presença de justa causa? Ao que parece, o responsável será o guarda de trânsito, desprovido de conhecimento técnico-científico para tanto ${ }^{29}$.

Isto posto, é imperioso concluir pela imprescindibilidade da comprovação da concentração igual ou superior a seis decigramas de álcool por litro de sangue para que o delito de embriaguez ao volante se perfaça, tendo em vista a necessidade basilar de tipicidade para que um crime se constitua.

A melhor doutrina elenca o exame de sague e o etilômetro como os possíveis meios de prova da elementar exigida pelo tipo penal. In verbis:

[...] mesmo que embriagado (e cada ser humano tem sua própria receptividade e tolerância ao álcool), poderá o sujeito estar dentro da

27 DUAILIBI, Sérgio, LARANJEIRA, Ronaldo. $O$ bafômetro $e$ a "lei seca". Disponível em http://www.ibccrim.org.br. Acesso em 06.07.2010.

${ }^{28}$ Exempli gratia, Rogério Schietti Machado Cruz.

${ }^{29}$ Ressalte-se que não se trata de desmerecer o relevante ofício que desempenham, mas simplesmente de relembrar que os mesmos não possuem formação médica, de modo que não estão aptos a avaliar legitimamente a presença de sinais externos de embriaguez. 
margem de tolerância prevista pelo legislador como insignificante e, s.m.j, a olhos nus, ainda nenhum ser humano possui o dom de analisar taxas de alcoolemia, sem se valer de algum instrumento técnico ou científico ${ }^{30}$.

Tais provas [...] consistirão, principalmente, nas declarações de testemunhas e em parecer médico. Essas provas poderão dizer se o motorista estava ou não alcoolizado, mas não em que grau, frustrando os objetivos da nova lei de punir [...] penalmente, aquele que estivesse com 6 decigramas ou mais ${ }^{31}$.

Desta forma, em que pesem os esforços enveredados por parte da doutrina e de profissionais para afastar testes e exames que exigem colaboração ativa por parte do motorista - e que, portanto, encontram obstáculo no princípio do nemo tenetur se detegere - fato é que a nova redação do art. 306 do CTB exige a comprovação da quantidade de álcool no sangue para que o delito nele previsto se perfaça e, portanto, ao menos nos termos da atual redação, a utilização de exames de sangue e do etilômetro revela-se indispensável ${ }^{32}$.

\subsection{A negativa de submissão ao teste do bafômetro e suas eventuais consequências}

\footnotetext{
${ }^{30}$ PEREIRA, Danilo. Bom-bons criminosos, imposição de bafômetro e prisões: o Estado de Polícia. Disponível em http://www.ibccrim.org.br. Acesso em 09.06.2010.

${ }^{31}$ DELMANTO, Roberto. As inconstitucionalidades da LEI SECA. Disponível em http:// www.ibccrim.org.br. Acesso em 09.06.2010.

32 Neste sentido já se posicionaram diversos Tribunais distribuídos pelo país, valendo destacar a Apelação Criminal no 2008.042.790-1, TJ/SC; Apelação Criminal no 2005.071.024796-2, TJDFT; SER $n^{\circ}$ 556839-0, TJ/PR, Segunda Câmara Criminal, Rel.Lilian Romero, j.28.05.09; Apelação Crime $n^{\circ}$ 70028634343, TJ/RS, $3^{\mathrm{a}}$ Câmara Criminal, Rel. Marco Antônio Ribeiro de Oliveira, j. 08.05.2009 e Processo nº 1.0056.07137602-6/001, TJ/MG, Rel. José Antonino Baía Borges, DJe 08.05.2009. No que tange ao STJ, pode-se afirmar, através de uma detida análise de seus pronunciamentos, que a Quinta Turma, até o segundo semestre do ano de 2011, remanescia atada a um posicionamento atentatório à legalidade, enquanto a Sexta Turma, atenta àquela e à tipicidade, considerava imprescindível a quantificação de álcool no sangue para que se perfizesse o delito de embriaguez ao volante, sendo valiosa, neste último sentido, a consulta ao $\mathrm{HC} \mathrm{n}^{\circ} 166.377 / \mathrm{SP}$, Ministro OG Fernandes, Sexta Turma, DJe 01.07.2010. Contudo, a Quinta Turma, no Ag Rg no Ag no 1.291.648/RS, julgado em 27.09.2011 e relatado pela Ministra Laurita Vaz, alterou seu entendimento, indo ao encontro do entendimento da Sexta Turma ao consignar que "A nova redação do crime de embriaguez ao volante exige, para caracterizar a tipicidade da conduta, seja quantificado o grau de alcoolemia. Essa prova técnica é indispensável e só pode ser produzida, de forma segura e eficaz, por intermédio do etilômetro ou do exame de sangue".
} 
Uma vez estabelecida a imprescindibilidade do teste do bafômetro enquanto meio de prova para fins de tipificação do delito de embriaguez ao volante, passemos à análise da possibilidade do indivíduo negar-se a "soprar" o bafômetro e os efeitos de tal recusa.

\subsection{1 $\underline{\text { A possibilidade de negativa à submissão as teste do bafômetro }}$}

A possibilidade de o motorista recusar-se a colaborar com a realização do teste do etilômetro emana da garantia constitucional à não auto-incriminação, a qual assegura ao indivíduo a possibilidade legítima de negar-se a participar ativamente de qualquer procedimento que possa resultar na produção de prova contra ninguém menos que si mesmo.

Enquanto direito fundamental, ao princípio do nemo tenetur se detegere deve ser dispensada interpretação ampla, devendo o mesmo permear o ordenamento jurídico como um todo e servir de diretriz à concretização de suas prescrições, podendo, inclusive, incidir diretamente sobre o caso concreto, tendo em vista a aplicabilidade direta das normas presentes na Constituição Federal de 1988.

No que tange ao teste do etilômetro, a doutrina, em sua grande maioria, entende não ser o condutor obrigado a submeter-se ao mesmo, embora haja divergências quanto às consequências dessa negativa.

Neste sentido, merecem destaque as lições de Roberto Delmanto e Luiz Flávio Gomes. Vejamos:

Trata-se do direito do acusado de não se auto-incriminar, de não fazer prova contra si mesmo, inclusive não se submetendo ao bafômetro ou a exame de sangue ${ }^{33}$.

A premissa básica aqui é a seguinte: ninguém está obrigado a fazer prova contra si mesmo. O sujeito não está obrigado a ceder seu corpo ou parte dele para fazer prova. Em outras palavras: não está obrigado a ceder sangue, não está obrigado a soprar o bafômetro ${ }^{34}$.

\footnotetext{
${ }^{33}$ DELMANTO, Roberto. As inconstitucionalidades da LEI SECA. Disponível em http://www.ibccrim.org.br. Acesso em 23.07.2010.

${ }^{34}$ GOMES, Luiz Flávio. Lei seca (Lei $n^{o}$ 11.705/2008). Exageros, equívocos e abusos das operações policiais. Disponível em http://jus2.uol.com.br/doutrina/texto.asp?id=11496. Acesso em 05.05.2010.
} 
Contudo, parte da doutrina, de forma totalmente alheia ao direito fundamental à não produção de provas contra si mesmo, aduz que o motorista possui o dever de se submeter aos testes de alcoolemia, não lhe sendo dado negar-se à sua realização ${ }^{35}$.

Neste passo, Eugênio Pacelli consigna que, para que as intervenções corporais sejam legítimas, é preciso haver previsão legal e uma infração penal para cuja comprovação seja imprescindível exame pericial técnico, sendo também necessário controle judicial, apenas excepcionável em situações de urgência inadiável ${ }^{36}$.

Segundo o doutrinador, a ingerência corporal necessária à comprovação de concentração de álcool no organismo possuiria previsão legal expressa (art. 277 do CTB), de modo que preencheria, em tese, as exigências exigidas para a aplicação de modalidades probatórias análogas ${ }^{37}$.

Apresentando fundamentos distintos, embora com o mesmo resultado prático, André Luís Callegari e Fábio Motta Lopes apregoam que o princípio do nemo tenetur se detegere se impõe em termos absolutos no que se refere à comprovação de embriaguez ao volante. Contudo, haveria a possibilidade de mitigação desse princípio caso fosse editada norma neste sentido:

Também não se está afirmando, em momento algum, que nunca será possível submeter-se motorista sob suspeita de dirigir embriagado, mesmo contra a sua vontade, a exame de sangue, por não ser a garantia ao silêncio um direito absoluto. Para isso, no entanto, deve haver uma legislação que discipline o assunto de forma detalhada $[\ldots]^{38}$.

Em que pesem as posições supra colacionadas, certamente baseadas em profundo saber jurídico, não se pode olvidar do caráter constitucional do princípio do nemo tenetur se detegere e das consequências que tal posição hierárquica acarreta.

\footnotetext{
${ }^{35}$ É este o posicionamento de André Luís Marinho Sampaio, segundo o qual a questão residiria em um sopesamento entre as garantias constitucionais da tutela da intimidade do indivíduo e da integridade física da coletividade, devendo prevalecer a que protege o bem jurídico de maior interesse social, qual seja, a integridade física das pessoas em geral. SAMPAIO, André Luís Marinho. O "bafômetro" na Lei $n^{\circ}$ 9.503/97. Código de trânsito brasileiro - CTB. Disponível em http://www.ibccrim.org.br. Acesso em 09.07.2010.

${ }^{36}$ OLIVEIRA, Eugênio Pacelli de. Curso de Processo Penal. Rio de Janeiro: Lumen Juris, 2009, p. 345.

${ }^{37}$ Loc. cit.

${ }^{38}$ CALLEGARI, André Luís. LOPES, Fábio Motta. A imprestabilidade do bafômetro como prova no processo penal. Disponível em http://www.ibccrim.org.br. Acesso em 24.05.2010.
} 
Como é cediço, a Constituição encontra-se no ápice do sistema jurídico, de modo que todas as demais normas devem com ela se coadunar, sob pena de serem reputadas inconstitucionais ou, no mínimo, não recepcionadas pelo advento da Lei Maior. Resta claro, portanto, que nenhuma norma infraconstitucional pode conflitar com uma de caráter constitucional.

Ora, se assim o é, com muito maior razão não pode uma mera norma administrativa (no caso, o art. 277 do CTB) pretender afastar um princípio constitucional, impondo sanções àquele que fizer valer seu direito à não produzir prova contra si mesmo, tendo em vista sua patente posição de inferioridade no âmbito do ordenamento jurídico.

Não é demais relembrar que a garantia à não auto-incriminação está inserta no rol de direitos e garantias fundamentais da Constituição Federal de 1988 (art. 5º LV e LXII), configurando-se como verdadeiro princípio basilar do Estado Democrático de Direito.

Neste diapasão, não se pode conferir a um determinado princípio ou garantia caráter absoluto, mesmo porque, na própria Lei Maior, alguns deles em franca dissonância uns com os outros. Apesar da inegável existência de conflitos, certo é que os mesmos não podem ser resolvidos a priori, sendo indispensável uma ponderação entre os princípios antagônicos à luz do caso concreto, cabendo salientar que, em hipótese alguma, pode o núcleo de um ser esvaziado por meio da atividade ponderativa.

Desta forma, conclui-se novamente o quão infeliz é a atual redação do art. 306 do CTB, sendo patente a frustração dos objetivos do legislador, o qual, ao invés de oferecer maior punição aos motoristas embriagados, na realidade criou diversas dificuldades probatórias e, consequentemente, punitivas.

O condutor pode, assim, legitimamente opor-se à realização do teste do bafômetro, de modo que sua conduta configurará exercício regular de um direito sendo, em tese, impunível $^{39}$. Todavia, a discussão acerca da possibilidade - ou não - de punição está longe de ser pacífica, como veremos a seguir.

\footnotetext{
${ }^{39}$ A tendência jurisprudencial atual é em contemplar e tutelar o direito à não produção de prova em desfavor próprio, sendo legítima a recusa em submeter-se ao etilômetro, eis que ninguém é obrigado a produzir prova contra si mesmo. Neste sentido, vide enunciado n 238 do STJ, HC 166.377-SP, Rel. Og Fernandes, j. 10.6.2010; Apelação Criminal n ${ }^{\circ}$ 990.09.246557-0, TJ/SP, Rel. Sidnei de Oliveira Jr., j. 25.02.2010 e Reexame Necessário $\mathrm{n}^{\circ}$ 0081325-77.2009.8.19.0001, TJ/RJ, Rel. Maldonato de Carvalho, Primeira Câmara Cível, j. 15.07.2010.Vale, por fim, destacar o valioso conteúdo didático presente em decisão proferida no HC $\mathrm{n}^{\circ}$ 004182689.2009.8.19.0000, TJ/RJ, Oitava Câmara Criminal, Rel. Gilmar Augusto Teixeira, j. 18.11.2009, a qual vem
} 


\subsubsection{As consequências da recusa à realização do teste do bafômetro}

A problemática dos efeitos da não submissão aos testes de alcoolemia possui como epicentro o art. 277 do CTB, responsável por prever a aplicação das penalidades e medidas administrativas elencadas no art. 165 do mesmo diploma legal àqueles que se negarem a "soprar" o etilômetro ou a fornecer amostras do próprio sangue.

Tal disposição, contudo, é manifestamente inconstitucional, tendo em vista sua pretensão em impor sanções aos condutores que apenas exercem direito assegurado pela própria Constituição Federal.

Afinal, conforme exposto ao longo do presente trabalho, não pode uma norma de cunho administrativo excluir a aplicabilidade de uma de status constitucional, sendo certo que, caso tal situação ocorresse, representaria uma paradoxal subversão ao sistema jurídico em vigor.

Inobstante a conclusão alcançada pela linha de pensamento até então explanada, a doutrina controverte quanto aos efeitos da negativa em tela, havendo quem defenda a configuração do crime de desobediência, a possibilidade de prisão em flagrante e, ainda, a incidência das sanções do art. 165 do CTB. Vejamos.

\subsubsection{A configuração do delito de desobediência}

A concepção de que a negativa de colaboração com os testes de alcoolemia acarretaria a imputação do crime de desobediência (art. 330 do Código Penal) ganhou notoriedade com o parecer $\mathrm{n}^{\circ} 121$ da Advocacia Geral da União (AGU), datado de 09 de julho de $2009^{40}$.

Tal parecer, em uma tentativa desesperada de punir o motorista embriagado, chegou a consignar que "não existe na Constituição, de forma expressa, dispositivo prevendo que ninguém seja obrigado a produzir provas contra si", concluindo, quanto ao etilômetro, que "a obrigatoriedade do cidadão submeter-se ao teste, além de ser legalmente permitida, constitui meio importante para a preservação da vida, [...] sendo, portanto, legítimo seu uso" ${ }^{41}$.

sendo utilizada por diversos magistrados de primeiro grau para fins de não recebimento da denúncia, com base na inépcia da mesma.

${ }^{40}$ Trata-se de parecer interno da AGU, distribuído ao Departamento de Polícia Rodoviária Federal com o escopo de padronizar os procedimentos dos agentes, os quais se utilizariam do mesmo, no momento da abordagem do motorista, para efetuar a prisão, segundo informação do sítio http://www.conjur.com.br. Acesso em 27.03.2010.

${ }^{41}$ Parecer n ${ }^{\circ} 121$ da AGU, de 09.07.2009. Disponível em http:// www.conjur.com.br. Acesso em 23.07.2010. 
Trata-se de entendimento nitidamente equivocado, vislumbrado na incessante tarefa de prender a qualquer custo o condutor em estado de ebriez, tendo em vista as dificuldades probatórias envolvidas na questão. Certamente não é por meio da imputação - data venia, absurda - do delito de desobediência que a controvérsia será resolvida.

Felizmente, a Polícia Rodoviária Federal, por meio da Instrução Normativa $\mathrm{n}^{\circ}$ 03/2009 ${ }^{42}$, rechaçou a possibilidade de prisão do motorista com base no art. 330 do Código Penal. Afinal, como bem destaca Luiz Flávio Gomes:

Se a recusa ao bafômetro é um direito constitucional e internacional (por força da Convenção Americana de Direitos Humanos, art. $8^{\circ}$, que encontra amparo no art. $5^{\circ}, \S 2^{\circ}$, da $\mathrm{CF}$ ), quem exerce um direito pratica ato lícito e quem pratica ato lícito não comete crime ${ }^{43}$.

Assim, tem-se que não há qualquer dever, por parte do indivíduo, de colaborar para a realização do teste de alcoolemia, mas, pelo contrário: este possui o direito de não se submeter ao mesmo, sem que tal recusa configure crime.

\subsubsection{A possibilidade da prisão em flagrante}

Em tese, a prisão em flagrante seria possível diante da constatação do crime de embriaguez ao volante, ou seja, na hipótese ficar comprovado, no momento da abordagem do motorista pela fiscalização de trânsito, que o mesmo encontrava-se dirigindo embriagado e influenciado pelo álcool previamente ingerido.

Os defensores da dispensabilidade do teste do bafômetro e do exame de sangue entendem ser possível a prisão em flagrante com base em uma embriaguez considerada "patente", de modo que, apresentando o condutor comportamento aparentemente influenciado

\footnotetext{
${ }^{42}$ A Instrução Normativa 03/2009 tem por finalidade a disciplina dos procedimentos na fiscalização do consumo de álcool por motoristas. Apregoa que a recusa a submeter-se ao bafômetro ou a exame de urina não configura infração, salvo no caso de ocorrência de crimes, como o envolvimento em acidentes e a fuga de operações. Ademais, a Instrução serve de diretriz para a abordagem de motoristas por parte dos agentes rodoviários, prevendo condutas e cuidados a serem observados, como, por exemplo, atentar para uma lista de sintomas elaborada pela Associação Brasileira de Medicina de Tráfego (Abramet), permitir aos motoristas, caso discordem do primeiro resultado, a realização de um segundo teste após um intervalo de 15 minutos e respeitar uma tabela com índices de tolerância para as medições. Disponível em www.dprf.gov.br.

${ }^{43}$ GOMES, Luiz Flávio. Embriaguez ao volante (art. 306 do CTB). Um erro atrás do outro. Disponível em http://jus2.uol.com.br/doutrina/texto.asp?id=13635. Acesso em 07.03.2010.
} 
pela bebida alcoólica, este poderia ser levado preso, independentemente da confirmação da quantidade de álcool em seu sangue. ${ }^{44}$

Aduzindo argumentação diametralmente oposta, aqueles que reputam o teste do bafômetro e o exame de sangue como meios indispensáveis para que o delito em comento se configure entendem apenas ser possível a prisão em flagrante na hipótese de efetiva confirmação da materialidade do crime em questão:

[...] apenas poderá haver a prisão em flagrante se o condutor admitir fazer exame ou teste de alcoolemia capaz de aferir as taxas. [...] Assim, v.g., o condutor que apesar de totalmente embriagado e colocando em risco a incolumidade de outrem na condução do veículo, não chega a atingir estes limites legais, não há que se falar em crime ${ }^{45}$.

Este entendimento é o que melhor se coaduna com a ordem jurídica em vigor, especialmente com os princípios do nemo tenetur se detegere e da reserva legal, todos de base constitucional (art. 5 , LXII e XXXIX, da Constituição Federal, respectivamente).

Destarte, é imprescindível a realização do teste do bafômetro ou do exame de sangue para que a prisão em flagrante passe a figurar como opção. Contudo, tendo em vista a possibilidade de recusa legítima à submissão a tais procedimentos, em verdade, a prisão em tela apenas ocorrerá se houver colaboração do condutor para tanto, colaboração esta que ficará ao alvedrio do mesmo.

\subsubsection{A aplicabilidade das sanções previstas pelo art. 165 do CTB}

No que tange à aplicabilidade - ou não - das sanções elencadas no art. 165 do CTB face à negativa de submissão a um dos testes de alcoolemia legalmente previstos, pode-se identificar três correntes: para a primeira, a negativa a qualquer espécie de exame ou teste implicaria nas sanções em comento; de acordo com a segunda, apenas a negativa à realização do exame clínico poderia ser objeto de sanção e, por fim, segundo a terceira corrente, as sanções elencadas jamais seriam aplicáveis, sob pena de violação à Lei Maior.

\footnotetext{
44 Neste sentido posiciona-se, a título de exemplificação, Bruno Freire de Carvalho Calabrich. $O$ teste do bafômetro $e$ a nova lei de trânsito.Aplicação $e$ conseqüências Disponível em http://jus2.uol.com.br/doutrina/texto.asp?id=11461. Acesso em 30.05.2010.

${ }^{45}$ PEREIRA, Danilo. Bom-bons criminosos, imposição de bafômetro e prisões: o Estado de Polícia. Disponível em http://www.ibccrim.org.br. Acesso em 09.06.2010.
} 
Sustentando a primeira e mais radical posição, temos Bruno Freire de Carvalho Calabrich, para quem a recusa de realização do teste do bafômetro acarretaria para o motorista todas as sanções previstas no art. 165 do CTB, sendo certo que, enquanto a aplicação da pena de multa e de suspensão do direito de dirigir demandariam um processo administrativo para que se efetivassem, a apreensão da carteira de motorista e a retenção provisória do veículo poderiam ser aplicadas imediatamente pelo agente de trânsito no momento da abordagem do condutor $^{46}$.

Nota-se, destarte, que, na hipótese de recusa a participar ativamente de qualquer um dos procedimentos elencados no art. 277 do CTB, nasceria verdadeira presunção em desfavor do indivíduo no que se refere às medidas administrativas. Embora tal presunção apresente caráter relativo, não se pode admitir sequer o surgimento da mesma, eis que atentatória ao princípio do nemo tenetur se detegere.

A segunda corrente, capitaneada por Luiz Flávio Gomes, leciona no sentido de não ser de forma alguma obrigatória a submissão ao teste do bafômetro, de modo que eventual negativa por parte do condutor não poderia acarretar nenhuma espécie de sanção, nem mesmo as elencadas no artigo em comento. Contudo, defende também o mestre que, uma vez afastado o teste do etilômetro, restaria a opção do exame clínico, o qual, caso negado, acarretaria a aplicação das sanções previstas em Lei. In verbis:

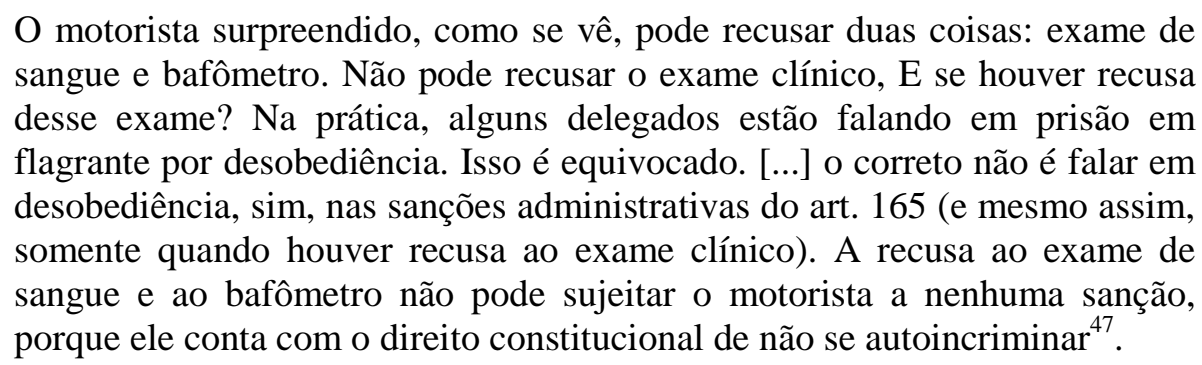

Todavia, não se pode olvidar que o princípio do nemo tenetur se detegere não possui aplicabilidade somente nos casos em que uma intervenção corporal se faz necessária, mas em todos os casos em que é exigida uma conduta ativa por parte do acusado. Deste modo, seria plenamente legítima a recusa do mesmo a comparecer ao Instituto Médico-Legal para

\footnotetext{
${ }^{46}$ Loc. cit.

${ }^{47}$ GOMES, Luiz Flávio. Lei seca (Lei $n^{o}$ 11.705/2008). Exageros, equívocos e abusos das operações policiais. Disponível em http://jus2.uol.com.br/doutrina/texto.asp?id=11496. Acesso em 05.05.2010.
} 
submeter-se ao exame clínico ou mesmo a praticar qualquer das ações típicas deste, como fazer o "quatro", andar em linha reta, tocar o próprio nariz, dentre outras.

Feitas essas considerações, passemos ao terceiro posicionamento, defendido principalmente por Roberto Delmanto e Danilo Pereira, o qual se revela, dentre todos, o mais compatível e harmônico com a ordem jurídico-constitucional em vigor.

De acordo com este último entendimento, o motorista abordado pela fiscalização viária poderia se negar a realizar o exame de sangue, o teste do bafômetro e também o exame clínico, ou seja, seria plenamente legítima eventual negativa em face qualquer meio de prova que envolvesse a participação ativa do condutor do veículo.

Neste sentido, segundo Delmanto, o art. 277 do CTB estaria em franca incompatibilidade com a Constituição Federal, sendo, em verdade, inconstitucional, tendo em vista que "ninguém pode ser punido, ainda que administrativamente, por ter exercido um direito" ${ }^{, 48}$.

Ainda sob esta perspectiva, merecem destaque as palavras de Danilo Pereira:

Esta previsão de sanção, sem análise da tolerância que o legislador constituiu é ilegal. Inclusive, vamos mais além e dizer que é totalmente inconstitucional. O cidadão não é obrigado a fazer prova contra si (nemo tenetur se detegere), ou seja, pode negar-se a soprar o bafômetro, não permitir que lhe colham sangue e tampouco é obrigado a andar em linha reta ou fazer movimentos como o famigerado "quatro".

Torna-se indiscutível a inconstitucionalidade dessa presunção de embriaguez superior ao limite legal, vez que há nítida imposição de constituição de prova pelo próprio condutor, num sistema cuja Constituição Federal, no próprio processo penal, que é o mais, assim não admite. O que dizer de um procedimento administrativo, que é o menos? Só resta ao agente de trânsito convidar o condutor a fazer tais exames. Em havendo negativa por parte do condutor, não pode obrigá-lo ou mesmo ameaçá-lo de prisão por crime de desobediência, tampouco obrigá-lo a gesticular, ou andar em linha reta, ou a fazer qualquer movimento corporal, sob pena de praticar-se crime de abuso de autoridade ${ }^{49}$.

Apesar da solução insatisfatória e frustrante que resulta deste entendimento, é forçoso admitir que não há, na atual configuração da legislação de trânsito, outra saída que preserve, simultaneamente, o respeito aos princípios da legalidade e da supremacia da Constituição.

\footnotetext{
${ }^{48}$ DELMANTO, Roberto. As inconstitucionalidades da LEI SECA. Disponível em http://www.ibccrim.org.br. Acesso em 12.08.2010

${ }^{49}$ PEREIRA, Danilo. Bom-bons criminosos, imposição de bafômetro e prisões: o Estado de Polícia. Disponível em http://www.ibccrim.org.br. Acesso em 09.06.2010.
} 
Afinal, com a mudança levada a cabo pela Lei 11.705/2008, é imprescindível que se confirme a quantidade limítrofe de álcool por litro de sangue para que ocorra a configuração do delito de embriaguez ao volante, verificação esta que somente pode ser realizada através do exame de sangue ou do teste do bafômetro. Contudo, tais meios de prova apenas serão legítimos caso sua realização conte com a participação voluntária do condutor, mediante decisão livre de qualquer sorte de coação.

Adicione-se ainda que o agente de trânsito deve comunicar o condutor acerca de seu direito à não produzir prova contra si mesmo, dever este que se pode extrair da interpretação conforme do art. $5^{\circ}$, LXIII, da Constituição Federal.

Neste sentido posicionam-se André Luís Callegari e Fábio Motta Lopes, aduzindo que:

[...] como não está obrigado a produzir prova contra si mesmo, deve ser avisado sobre tal direito antes de ser submetido aos testes de alcoolemia. Inobservada tal garantia, deverá o resultado do bafômetro, tão-somente pelo fato de não se assegurar ao motorista o direito de informação, ser considerado como prova ilícita (art. $5^{\circ}, \mathrm{LVI}$, da CF, e art. 157 , caput e $\S \S$, do CPP) ${ }^{50}$.

Eugênio Pacelli de Oliveira, por sua vez, é preciso ao destacar que, caso não houvesse a exigência de advertência por parte das autoridades policiais e judiciais ao réu do seu direito de permanecer em silêncio em audiência (art. 186 do CPP), o princípio jamais seria observado na prática. Assim, tal exigência seria uma consequência lógica da aplicação ao direito ao silêncio, sendo indispensável, sob pena de nulidade ${ }^{51}$.

Seguindo o mesmo raciocínio jurídico, constitui dever daqueles responsáveis pela abordagem do motorista informar ao mesmo acerca do seu direito à não produzir prova em desfavor próprio, sendo certo que, caso tal advertência não ocorra, a prova eventualmente colhida estará eivada de ilicitude.

Desta forma, em suma, tem-se que, diante da atual redação do art. 306 do CTB, para que o delito de embriaguez ao volante se perfaça:

1. É imprescindível a comprovação de concentração igual ou superior a seis decigramas de álcool por litro de sangue e da direção anormal;

2. O condutor pode legitimamente se negar a colaborar com a realização do teste

\footnotetext{
${ }^{50}$ CALLEGARI, André Luís; LOPES, Fábio Motta. A imprestabilidade do bafômetro como prova no processo penal. Disponível em http:// www.ibccrim.org.br. Acesso em 24.05.2010.

${ }^{51}$ OLIVEIRA, Eugênio Pacelli de. Curso de Processo Penal. Rio de Janeiro: Lumen Juris, 2009, p. 344.
} 
do bafômetro ou do exame de sangue, sendo certo que tal recusa não importará em:

(i) crime de desobediência;

(ii) prisão em flagrante ou

(iii) aplicação de qualquer das sanções previstas no art. 165 do CTB.

\section{CONCLUSÕES}

A alteração realizada pela Lei $n^{\circ} 11.705 / 2008$ na redação do art. 306 do CTB certamente não foi das mais felizes. A Lei, que buscava uma maior punição dos motoristas que deliberadamente conduzem seus veículos embriagados, causando diversos acidentes muitas vezes fatais - acabou não apenas frustrando seus próprios objetivos, como tornando ainda mais difícil a responsabilização criminal dos condutores.

A nova redação do art. 306 do CTB, conta agora com duas elementares, que devem ser devidamente comprovadas para que ocorra a tipicidade e, consequentemente, a conduta delitiva: a concentração de álcool por litro de sangue superior seis decigramas e a direção influenciada pelo álcool, esta última representada por atos como dirigir em "zigue-zague", ultrapassar sinais vermelhos, não respeitar a faixa em que conduz, dentre outras.

Ressalte-se, mais uma vez, que ambas as elementares devem estar devidamente comprovadas, sob pena de afronta aos princípios da legalidade estrita e da tipicidade, orientadores do Direito Penal.

No âmbito da redação anterior do dispositivo em comento, bastava a direção influenciada pelo álcool, não havendo previsão de concentração específica dessa substância no sangue. Todavia, com a previsão de tal concentração torna-se imprescindível que a mesma confirmada em termos exatos, o que somente pode ser feito por instrumentos técnicos, no caso, o exame de sangue e o etilômetro.

Assim, é absolutamente inaceitável que a prova técnica possa ser suprida por impressões subjetivas dos agentes da fiscalização de trânsito, sem nenhuma qualificação técnica para tanto. Aliás, mesmo médicos, por melhor que seja sua formação e por mais vasta que seja sua experiência profissional, não estão aptos a atestar se o condutor perfaz ou não a 
nova exigência legal, eis que somente instrumentos precisos são capazes quantificar a concentração de substâncias químicas no corpo humano.

Tal restrição probatória acaba por acarretar uma série de impunidades, tendo em vista a inexistência de etilômetros suficientes em todas as cidades do país e a dificuldade de realização do exame de sangue, normalmente feito em local diverso daquele em que ocorre a fiscalização, de modo que muitas vezes, ao ser realizado, o álcool já foi absorvido pelo organismo.

Além das dificuldades específicas de cada meio probatório, há ainda uma que se aplica a ambos: a possibilidade de o motorista legitimamente negar-se a realizar qualquer deles, com base em seu direito de não produzir prova contra si mesmo.

Este direito, previsto pelo art. $8^{\circ}$, número 2, letra "g" do Pacto de San Jose da Costa Rica, do qual é Brasil é signatário (Decreto $n^{\circ}$ 678/92) e erigido a garantia fundamental pela Constituição Federal de 1988 (artigo 5, inciso LXIII), tem recebido interpretação ampla por parte da doutrina e da jurisprudência, aplicando-se não apenas no âmbito do direito ao silêncio, mas a qualquer meio de prova que exija conduta ativa por parte do acusado ou suspeito de cometer um delito.

Desta forma, tem-se que o condutor suspeito apenas se submeterá ao teste do bafômetro se assim o desejar, não podendo ser compelido a fazê-lo pelos agentes da fiscalização ou mesmo punido por sua recusa, eis que estará exercendo garantia constitucionalmente conferida ${ }^{52}$.

Embora nenhum direito fundamental possua caráter absoluto, certo é que, em caso de conflito, deve haver uma ponderação entre os direitos em questão à luz do caso concreto. Assim, não se pode, aprioristicamente, afastar o princípio do nemo tenetur se detegere, por meio de lei infraconstitucional - como pretende a Lei ${ }^{\circ} 11.705 / 2008$-, sendo qualquer lei neste sentido eivada de inconstitucionalidade. Adicione-se ainda que a lei em estudo rechaça por completo a garantia à não auto-incriminação, de modo que esvazia o núcleo da mesma, o que não pode ser admitido em nenhuma atividade interpretativa levada a cabo em um Estado Democrático de Direito.

\footnotetext{
${ }^{52}$ Neste sentido, tramita atualmente no Supremo Tribunal Federal a Ação Direta de Inconstitucionalidade $n^{\circ}$ 4.103-DF, interposta pela Associação Brasileira de Restaurantes e Empresas de Entretenimento, no sentido de ver declarada a inconstitucionalidade da Lei $\mathrm{n}^{\circ} 11.705 / 2008$, ainda pendente de julgamento.
} 
Estando a Constituição Federal no ápice do ordenamento jurídico e tendo conferido à garantia em estudo caráter fundamental, seu exercício não pode ser acarretar qualquer espécie de sanção, seja de cunho penal, seja de cunho administrativo, de modo que se revela completamente ilegal eventual imputação de crime de desobediência ou mesmo das sanções elencadas no art. 165 do CTB face à negativa de "soprar" o bafômetro.

Do mesmo modo, não será legitimamente possível ocorrência de prisão em flagrante sem a colaboração do condutor, de modo que, em verdade, este apenas será levado preso se aceitar fornecer provas potencialmente incriminadoras, após ter sido advertido pelos agentes de trânsito de seu direito à não fazê-lo. Caso não haja tal advertência, mesmo que se submeta ao teste do bafômetro ou ao exame de sangue, estas provas serão ilícitas, eis que obtidas em violação à garantia fundamental contemplada na Lei Maior.

Uma vez constatada a concentração de álcool por litro de sangue acima do legalmente permitido, deve-se passar à comprovação da segunda elementar, ou seja, verificar se o condutor estava dirigindo sob influência do álcool, sendo esta imprescindível para que o delito em tela se configure, eis que o tipo penal do art. 306 do CTB exige a presença perigo concreto e não meramente abstrato, tendo em vista o princípio da ofensividade constitucionalmente tutelado (art. 98, I, CF).

Assim, caso o motorista, embora com mais de seis decigramas de álcool por litro de sangue, conduza seu veículo de forma impecável, não incorrerá no crime de embriaguez ao volante, tendo em vista que sua conduta será atípica e, portanto, impunível ${ }^{53}$.

Apesar da frustração e do anseio por justiça e punição que tal situação desperta, não se pode buscar corrigir um erro cometendo outro.

Destarte, não podem os órgãos do Poder Judiciário, buscando uma punição a qualquer custo, afastar um princípio tão fundamental ao Direito Penal como o da legalidade estrita, como se tem observado em algumas decisões, que dispensam a realização do exame de sangue e do emprego do etilômetro, creditando a agentes de trânsito ou a médicos a capacidade de atestar se o motorista possui exatos seis decigramas de álcool por litro de sangue. Resta a incômoda pergunta: e se o condutor possui 5,9 decigramas de álcool por litro

\footnotetext{
${ }^{53}$ A Lei nova impôs tamanhos óbices à prova que tem conduzido à impunidade, tanto que levantamento feito pela Justiça Estadual entre os anos de 2008 e 2009 constatou que $80 \%$ dos motoristas que se recusaram ao teste do bafômetro ou a fazer o exame de sangue para verificar a quantidade de álcool por litro de sangue acabaram sendo absolvidos. FOLHA de São Paulo 17.09.2009, p. C7. Disponível em http://www.lfg.com.br. Acesso em 09.08.2010.
} 
de sangue? Será punido sem perfazer a figura típica? É óbvio que somente por meio de instrumentos técnicos pode essa quantificação ser realizada e, consequentemente, caracterizado - ou não - o delito de embriaguez ao volante.

Do mesmo modo, é possível encontrar decisões que consideram a concentração de álcool no sangue acima do permitido em lei suficiente para que se perfaça o crime em comento, sem necessidade de haver a direção influenciada pelo álcool. Tal entendimento igualmente não merece prosperar, tendo em vista que a infração administrativa prevista pelo CTB exige a influência de álcool, de modo que seria paradoxal se a penal, que é o mais, não contivesse a mesma exigência.

Ademais, a direção influenciada pelo álcool é a responsável por representar ofensividade ao bem jurídico tutelado, caracterizando o perigo concreto indeterminado exigido pelo tipo penal. Assim, apenas o motorista que dirige de maneira anormal gera efetivamente perigo à vida ou à integridade física de outrem, o que não ocorre com aquele que, embora com concentração de álcool por litro de sangue acima do legalmente tolerado, dirige normalmente. Entender de modo diverso significa contemplar o perigo abstrato, inconstitucional frente ao princípio constitucional de lesividade.

Desta forma, não há, nos termos em que o delito está tipificado atualmente, como afastar a comprovação da concentração exata de álcool por litro de sangue e da efetiva direção influenciada pelo álcool, não havendo espaço para ativismo judicial na seara criminal.

A melhor solução para a questão é uma nova alteração legislativa, o quanto antes.

Neste sentido, deve-se exigir somente a influência de álcool para a caracterização do delito, o que poderá ser aferido sem a necessária colaboração do suspeito, por meio de sinais notórios de embriaguez, a serem constatados por médico-perito.

A especificidade matemática de concentração de álcool no sangue deve ser excluída da tipificação penal, de modo que qualquer comportamento viário influenciado pelo álcool será passível de punição, havendo, desta forma, a pretendida "tolerância zero".

Estudos demonstram que não há limites seguros para o consumo de bebidas alcóolicas em motoristas, tendo em vista que mesmo em baixas doses o álcool provoca prejuízos visuais, nos reflexos e na visão periférica, comprometendo da noção de distância, velocidade, atenção, coordenação e tempo de reação, alterando a capacidade de controle dos impulsos e 
aumentando a impetuosidade ${ }^{54}$, de forma que a fixação de concentrações específicas de álcool no sangue não apenas restringe os meios de prova como também pode ser perigosa, eis que diferentes pessoas apresentam distintas reações ao álcool.

Diante do exposto, mister se faz uma nova alteração do art. 306 do CTB, de modo que este possa, ao mesmo tempo, respeitar os direitos e garantias fundamentais previstos na Constituição Federal e punir com mais intensidade e severidade aqueles que insistem em colocar em risco a vida de pessoas inocentes.

Embora a edição de novas leis, em geral, não seja a melhor solução, neste caso certamente o é, tendo em vista que será a maneira mais eficaz de apaziguar a questão, diminuindo substancialmente o fluxo de habeas corpus e apelações nos Tribunais e atendendo aos anseios de justiça por parte da sociedade e de respeito à Constituição por parte dos profissionais do Direito.

Adicione-se que tantas são as leis supérfluas editadas e aprovadas no cotidiano, que certamente não poderá, razoavelmente, ser oposto à solução ora apresentada o argumento de que não deve a legislação ser alterada com tanta frequência, especialmente tendo em vista que o assunto refere-se à matéria criminal, cuja base é a legalidade estrita, não se admitindo analogia ou qualquer tipo de interpretação extensiva em desfavor do réu.

Ressalte-se, por derradeiro, que a alteração legislativa ora proposta afigura-se como de máxima urgência, tendo em vista não caber ao acusado, ao seu próprio alvedrio, optar em se submeter ou não à Lei Penal, discricionariedade esta que acaba por ser permitida pela lei vigente, possibilitando àquele que, neste momento, acaba de matar alguém devido à direção embriagada, a simples negativa a fornecer prova essencial à sua punição. Tal inversão de valores certamente não pode prevalecer.

\section{REFERÊNCIAS}

ADVOCACIA GERAL DA UNIÃO, Parecer $n^{\circ}$ 121, 09.07.2009. Disponível em http:// www.conjur.com.br. Acesso em 23.07.2010.

\footnotetext{
54 DUAILIBI, Sérgio, LARANJEIRA, Ronaldo. $O$ bafômetro $e$ a "lei seca". Disponível em http://www.ibccrim.org.br. Acesso em 06.07.2010.
} 
CALLEGARI, André Luís. LOPES, Fábio Motta. A imprestabilidade do bafômetro como prova no processo penal. Disponível em http://www.ibccrim.org.br. Acesso em 24.05.2010.

CRUZ, Rogério Schietti Machado. Embriaguez ao volante: recusa a produzir prova não exclui o crime. Disponível em www.ibbcrim.org.br. Acesso em 13.07.2010.

DELMANTO, Roberto. As inconstitucionalidades da LEI SECA. Disponível em http:// www.ibccrim.org.br. Acesso em 09.06.2010.

DUAILIBI, Sérgio, LARANJEIRA, Ronaldo. O bafômetro e a "lei seca". Disponível em http://www.ibccrim.org.br. Acesso em 06.07.2010.

GOMES, Luiz Flávio. A Constituição e os crimes de perigo abstrato. Disponível em http://www.lfg.com.br/public_html/article.php?story=20070214091633277. Acesso em 21.04.2010.

. Lei seca (Lei $n^{0}$ 11.705/2008). Exageros, equívocos e abusos das operações policiais. Disponível em www.jus2.uol.com.br/doutrina/texto.asp?id=11496. Acesso em 05.05.2010.

. Embriaguez ao volante (art. 306 do CTB). Um erro atrás do outro. Disponível em http://jus2.uol.com.br/doutrina/texto.asp?id=13635. Acesso em 07.03.2010.

JESUS, Damásio Evangelista de. Embriaguez ao volante: notas à Lei $\mathbf{n}^{\mathbf{0}}$ 11.705/2008. Disponível em http://jus2.uol.com.br/doutrina/texto.asp?id=11510. Acesso em 23.01.2010.

Notas ao art. 306 do Código de Trânsito: Crime de embriaguez ao volante. Disponível em http://www.ibccrim.org.br. Acesso em 23.06.2010

MACHADO, Nara Borgo Cypriano. O princípio do nemo tenetur se detegere a prova no processo penal. Disponível em http://www.bdjur.stj.gov.br. Acesso em 09.02.2010.

MARCONDES, João Guilherme. A política do bêbado zero e o tipo de perigo abstrato: análise da nova redação do Art. 306 do CTB. Disponível em http://www.ibccrim.org.br. Acesso em 27.06.2010.

NUCCI, Guilherme de Souza. Manual de Processo Penal e Execução Penal. São Paulo: 
Revista dos Tribunais, 2008.

OLIVEIRA, Eugênio Pacelli de. Curso de Processo Penal. Rio de Janeiro: Lumen Juris, 2009.

PEREIRA, Danilo. Bom-bons criminosos, imposição de bafômetro e prisões: o Estado de Polícia. Disponível em http://www.ibccrim.org.br. Acesso em 09.06.2010.

QUEIJO, Maria Elisabeth. O direito de não produzir prova contra si mesmo: o princípio do nemo tenetur se detegere e suas decorrências no processo penal. São Paulo: Saraiva, apud MACHADO, Nara Borgo Cypriano. O princípio do nemo tenetur se detegere e a prova no processo penal. Disponível em http://www.bdjur.stj.gov.br. Acesso em 16.03.2010.

QUEIROZ, Paulo. Direito Penal. Parte Geral. São Paulo: Saraiva, 2005, p. 157.

RANGEL, Paulo. Direito Processual Penal. Rio de Janeiro: Lumen Juris, 2009.

ROMERO, Diogo. Reflexões sobre os crimes de perigo abstrato. Disponível em http://www1.jus.com.br/Doutrina/texto.asp?id=5722. Acesso em 30.08.2010.

SAMPAIO, André Luís Marinho. O "bafômetro" na Lei no 9.503/97. Código de trânsito brasileiro - CTB. Disponível em http://www.ibccrim.org.br. Acesso em 09.07.2010. 